\title{
Joubert Syndrome and related disorders
}

\author{
Francesco Brancati 1,2 , Bruno Dallapiccola 3 and Enza Maria Valente ${ }^{* 1,4}$
}

\begin{abstract}
Joubert syndrome (JS) and related disorders (JSRD) are a group of developmental delay/multiple congenital anomalies syndromes in which the obligatory hallmark is the molar tooth sign (MTS), a complex midbrain-hindbrain malformation visible on brain imaging, first recognized in JS. Estimates of the incidence of JSRD range between 1/80,000 and 1/ 100,000 live births, although these figures may represent an underestimate. The neurological features of JSRD include hypotonia, ataxia, developmental delay, intellectual disability, abnormal eye movements, and neonatal breathing dysregulation. These may be associated with multiorgan involvement, mainly retinal dystrophy, nephronophthisis, hepatic fibrosis and polydactyly, with both inter- and intra-familial variability. JSRD are classified in six phenotypic subgroups: Pure JS; JS with ocular defect; JS with renal defect; JS with oculorenal defects; JS with hepatic defect; JS with orofaciodigital defects. With the exception of rare X-linked recessive cases, JSRD follow autosomal recessive inheritance and are genetically heterogeneous. Ten causative genes have been identified to date, all encoding for proteins of the primary cilium or the centrosome, making JSRD part of an expanding group of diseases called "ciliopathies". Mutational analysis of causative genes is available in few laboratories worldwide on a diagnostic or research basis. Differential diagnosis must consider in particular the other ciliopathies (such as nephronophthisis and Senior-Loken syndrome), distinct cerebellar and brainstem congenital defects and disorders with cerebro-oculo-renal manifestations.

Recurrence risk is $25 \%$ in most families, although X-linked inheritance should also be considered. The identification of the molecular defect in couples at risk allows early prenatal genetic testing, whereas fetal brain neuroimaging may remain uninformative until the end of the second trimester of pregnancy. Detection of the MTS should be followed by a diagnostic protocol to assess multiorgan involvement. Optimal management requires a multidisciplinary approach, with particular attention to respiratory and feeding problems in neonates and infants. Cognitive and behavioral assessments are also recommended to provide young patients with adequate neuropsychological support and rehabilitation. After the first months of life, global prognosis varies considerably among JSRD subgroups, depending on the extent and severity of organ involvement.
\end{abstract}

\section{Disease name and synonyms}

The term Joubert Syndrome and Related Disorders (JSRD) has been recently adopted to describe all disorders presenting the "molar tooth sign" (MTS) on brain imaging. Thus, JSRD include Joubert syndrome (JS, also known as Joubert-Boltshauser syndrome [OMIM\#213300]), as well as any related condition showing the MTS, such as the cerebello-oculo-renal syndrome, Dekaban-Arima syndrome [OMIM\%243910], $\mathrm{COACH}$ syndrome [OMIM216360], Varadi-Papp syndrome (or Orofaciodigital type VI, [OMIM\%277170]), Malta syndrome and a minority of cases with SeniorLoken syndrome [OMIM\#266900].

*Correspondence: e.valente@css-mendel.it

${ }^{1}$ Mendel Laboratory, Casa Sollievo della Sofferenza Hospital, IRCCS, San Giovanni Rotondo, Italy

Full list of author information is available at the end of the article

\section{Definition and diagnostic criteria}

Joubert syndrome (JS) was originally described in 1968 in four siblings with agenesis of the cerebellar vermis presenting episodic hyperpnoea, abnormal eye movements, ataxia and intellectual disability [1]. Several years later, a pathognomonic midbrain-hindbrain malformation, the "molar tooth sign" (MTS), was detected first in JS [2], and then in several other conditions previously considered as distinct entities [3] (see section "Disease name and synonyms"). The term "Joubert Syndrome and Related Disorders" (JSRD) was then coined to group all conditions sharing the MTS [4], and this neuroradiological sign now represents the mandatory criterion to diagnose JSRD.

The MTS results from hypo-dysplasia of the cerebellar vermis, abnormally deep interpeduncular fossa at the level of the isthmus and upper pons, and horizontalized, thickened and elongated superior cerebellar peduncles 

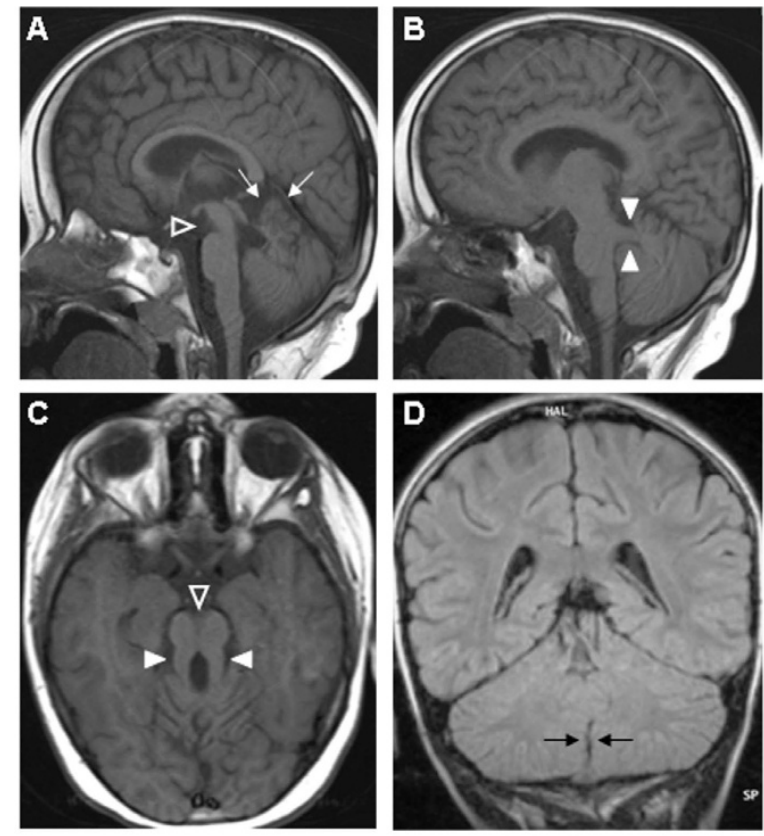

Figure 1 Brain MRI sections in patients with JSRD. A) mid-sagittal T1-weighted image shows a thin midbrain with corresponding enlargement of the interpeduncular fossa (open arrowhead). There is concurrent superior vermian dysplasia (thin arrows); B) parasagittal T1weighted image shows thickened and maloriented superior cerebellar peduncle (thick arrowheads); C) axial T1-weighted image confirms the deepened interpeduncular fossa (open arrowhead) and abnormal superior cerebellar peduncles (thick arrowheads), comprising the "molar tooth sign"; D) coronal FLAIR image shows midline cerebellar cleft (black arrows) indicating agenesis of the inferior vermis.

[5] (Figure 1). At the pathological level, these abnormalities correspond to a picture of severe hypo-dysplasia of the cerebellar vermis with midline clefting, fragmentation of cerebellar nuclei and heterotopia of Purkinje-like neurons, along with dysplasia of pontine and medullary structures such as the basis pontis, reticular formation, inferior olivary, dorsal column and solitary tract nuclei. Moreover, typical findings are represented by the lack of decussation both of the superior cerebellar peduncles and of the corticospinal tracts at the medullary pyramids $[1,6]$.

JSRD are clinically heterogeneous and combine neurological signs with variable multiorgan involvement, mainly of the retina, kidneys, liver and skeleton. This marked pleiotropism can probably be explained by the genetic basis of these syndromes. Ten causative genes have been identified to date: JBTS1/INPP5E [OMIM*613037], JBTS2/TMEM216 [OMIM*613277], JBTS3/AHI1 [OMIM*608894], JBTS4/NPHP1 [OMIM* 607100], JBTS5/CEP290 [OMIM*610142], JBTS6/TME M67 [OMIM*609884], JBTS7/RPGRIP1L [OMIM*61 0937], JBTS8/ARL13B [OMIM*608922], JBTS9/CC2D2A [OMIM*612013], JBTS10/OFD1 [OMIM*300170]. All these genes encode for proteins of the primary cilium, including JSRD in the group of "ciliopathies". Primary cilia are known to play key roles in the development and functioning of several cell types, including retinal photoreceptors, neurons, kidney tubules and bile ducts $[7,8]$. In the developing cerebellum and brainstem, these organelles regulate major signal transduction pathways, and have been implicated both in neuronal cell proliferation and axonal migration [9].

JSRD present genetic and clinical overlap with other ciliopathies, in particular with Meckel syndrome, a lethal malformative condition characterised by encephalocele, other posterior fossa anomalies, ductal plate malformation of the liver and polycystic kidneys. JSRD and Meckel syndrome phenotypes may represent the two ends of a continuum and, indeed, mutations in at least five genes (TMEM216, CEP290, TMEM67, RPGRIP1L and $C C 2 D 2 A)$ cause both disorders, with distinct mutation types variably correlating with the phenotypic severity [10-15]. Interestingly, preliminary genotype-phenotype correlates indicate that Meckel syndrome fetuses nearly invariably harbor truncating mutations, while at least one hypomorphic (e.g. missense) mutation is found in almost all JSRD cases $[11,13,14]$.

\section{Epidemiology}

Although the incidence of JSRD has not been precisely determined, it may range between $1 / 80,000$ and $1 /$ 100,000 live births, but may be underestimated $[16,17]$.

\section{Clinical description Neurological features}

The cardinal neurological features of JSRD are hypotonia evolving into ataxia and developmental delay, often associated with intellectual disability, altered respiratory pattern in the neonatal period and abnormal ocular movements [1,18-20].

Early hypotonia is observed in nearly all JSRD patients and can be recognized in the neonatal period or in infancy. Although hypotonia represents an unspecific finding of many neuropediatric disorders, its association with other peculiar features such as an irregular breathing pattern and altered eye movements should suggest the diagnosis of JSRD and prompt the clinician to request a brain magnetic resonance imaging. Patients often develop ataxia with broad-based gait in the first years of independent ambulation. These balance difficulties have been extensively reviewed [2] and, although non-specific, represent a frequent finding of JSRD. In some cases, tremor has been reported [20].

The typical respiratory abnormalities are represented by short alternate episodes of apnea and hyperpnea or episodic hyperpnea alone, which tend to occur shortly after birth, intensify with emotional stress and progres- 
sively improve with age, usually disappearing around the sixth month of life. Their severity can range from occasional short-lasting episodes manifesting every few days to extremely frequent (up to several per day) and prolonged attacks of apnea, requesting intensive care management and assisted ventilation $[1,21]$.

Abnormal eye movements also represent a recurrent feature in JSRD. Oculomotor apraxia is one of the most characteristic and frequent abnormalities, that manifests with the inability to follow objects visually with compensatory head movements, decreased smooth pursuit, and cancellation of the vestibulo-ocular reflex. Primary position nystagmus is also common, while occasionally associated features include strabismus and ptosis. Such manifestations are present independently from the specific defects of the eyes (see "Ocular features"), and relate to the underlying midbrain-hindbrain malformation [2,21-23].

Developmental abilities, in particular language and motor skills, are delayed in all JSRD patients, with variable degrees of severity [22,24-26]. Mild to severe intellectual disability is common, with several patients being able to attend special schools, learn specific job skills and work in protected conditions [27]. However, it must be stressed that intellectual deficit is not a mandatory feature of JSRD and exceptional cases may have borderline or even normal intellect. Siblings discordant for this feature have been recently reported, further emphasizing the difficulty to predict the neurological outcome in infants $[28,29]$.

A wide range of central nervous system (CNS) malformations are described in association to the MTS that can dramatically affect the clinical outcome and prognosis of patients with JSRD. These include hydrocephalus, cystic enlargement of the posterior fossa, abnormalities of the corpus callosum, white matter cysts, hypothalamic hamartoma, and absence of the pituitary gland [30-38]. Abnormal migration defects, mainly periventricular nodular heterotopia, and cortical organization defects such as polymicrogyria have also been reported $[39,40]$. Patients with these malformations present a higher incidence of epilepsy, which is otherwise a rare feature of JSRD $[32,39]$. Finally, a small number of cases present with occipital (meningo) encephalocele of variable severity $[1,34,41]$.

\section{Ocular features}

The retina is one of the organs most frequently involved in JSRD, mostly in the form of retinal dystrophy, due to progressive degeneration of photoreceptor cells. The clinical spectrum can range from congenital retinal blindness (also known as Leber congenital amaurosis - LCA), to retinal dystrophy characterized by a progressive course and variably conserved vision $[2,42-45]$. The diagnosis is based on the findings of reduced visual acuity, associated with abnormal fundus oculi and/or electroretinogram [3]. The association of LCA with nephronophthisis (NPH) defines the Senior-Loken syndrome that, in a subset of cases, also displays the MTS [3].

Colobomas can be unilateral or bilateral, and mostly affect the posterior segment of the eye. Such defects originate from a failure in fetal fissure closure, which results in colobomas involving the retinal pigmented epithelium, the neurosensory retina or the choroids [46]. Iris colobomas have been reported in few cases [3]. Colobomas represent a rare cause of visual impairment in all JSRD clinical subgroups, although their frequency reaches over $30 \%$ in the subgroup of JS with hepatic defect [47] (see "Classification of JSRD").

\section{Renal features}

Renal disease affects approximately $25 \%$ of patients with JSRD, presenting in most cases as NPH. This is a structural tubulo-interstitial disorder characterized by irregular, thickened basal membrane of the tubular epithelium and progressive interstitial fibrosis, associated with small cysts at the cortico-medullary junction. Juvenile NPH may remain asymptomatic for several years or present with subtle and often unrecognized signs such as polyuria and polydypsia, until acute or chronic renal insufficiency manifests in the late first or early second decade of life. End stage renal failure is usually reached by the end of the second decade, requiring dialysis or kidney transplantation. An infantile variant of NPH manifests within the first years of life, with a more rapid and severe course [48].

The association of MTS with cystic dysplastic kidney (CDK), characterized by abnormal metanephric development with macroscopically large kidneys and prominent cysts, prompted some authors to delineate a novel clinical entity termed Dekaban-Arima syndrome [OMIM 243910] [18,49,50]. However, a recent re-examination of some of the originally reported patients showed histological abnormalities more typical of NPH than of CDK, challenging the existence of Dekaban-Arima syndrome and suggesting that all JSRD present the same renal phenotype [51]. Of note, CDK is found in other ciliopathies and typically in the lethal Meckel syndrome [52,53].

\section{Hepatic features}

A minority of JSRD patients present liver disease, usually manifesting as congenital hepatic fibrosis (CHF). This results from an embryonic malformation of the ductal plate, with cystic dilatation of primitive biliary structures and fibrous enlargement of the portal tracts [54]. Liver disease may present with raised serum liver enzymes (alanine aminotransferase, aspartate aminotransferase and gamma-glutamyl transpeptidase) at least twice the nor- 
mal values, early onset hepato(spleno)megaly or more severe manifestations including portal hypertension, esophageal varices and liver cirrhosis $[47,55]$.

The association of JS with CHF was previously known by the acronym $\mathrm{COACH}$ (Cerebellar vermis hypoplasia, Oligophrenia, Ataxia, Coloboma and Hepatic fibrosis) $[55,56]$.

\section{Skeletal features}

Since the description of the first JS family, polydactyly has been often reported in JSRD with a frequency of about 8$16 \%[1,18,57]$.

The most common form is represented by postaxial polydactyly, variably affecting hands and feet [58]. The association of JS with polydactyly and oral defects defines a condition known as orofaciodigital type VI or VaradiPapp syndrome (OMIM 277170) [59]. In this case polydactyly is typically mesaxial with Y-shaped metacarpals.

Mild to severe scoliosis may represent a manifestation of JSRD and likely relates to the degree of hypotonia in early infancy, while structural anomalies of the vertebrae are uncommon [60].

\section{Miscellaneous}

Although JSRD are not typically dysmorphic syndromes, patients have a characteristic face, and a recent study has outlined the presence of peculiar craniofacial features and distinct anthropometric facial patterns, which tend to change with age $[20,61]$. Congenital heart defects are not typically associated with JSRD but have been reported occasionally [62]. Laterality defects such as complete situs inversus are also rare [63]. Hirschsprung's disease has been described so far in two patients with JSRD [64], but its frequency is likely to represent an underestimate. In fact, three individuals with Hirschsprung's disease were observed in a cohort of about 200 patients, suggesting that this association is not coincidental (Brancati and Valente, unpublished observation). Interestingly, Hirschsprung's disease is associated with another ciliopathy, Bardet-Biedl syndrome [65], and cilia have been recently implicated in neural crest development [66].

\section{Classification of JSRD}

The classification system of JSRD is still evolving due to the discovery of novel genes and the improved understanding of genotype-phenotype correlations.

The MTS has been initially described as part of distinct syndromes termed classical JS, JS plus LCA or retinal dystrophy, JS plus polymicrogyria, Senior-Loken, DekabanArima, $\mathrm{COACH}$, Varadi-Papp, and Malta syndromes [4]. Although useful in the past, we now discourage the continued use of such eponyms in favor of a more practical, clinical-genetic classification. The one proposed here defines six subgroups based on the main organ(s) involvement and the established genotype-phenotype correlates (Table 1). Additional features such as facial dysmorphism, polydactyly, colobomas, and other CNS malformations (e.g. encephalocele, abnormal neuronal migration, etc.) can be detected within all the following subgroups.

\section{Pure JS}

In addition to the MTS, patients display the cardinal neurological findings of hypotonia/ataxia and developmental delay, variably associated with irregular breathing, abnormal eye movements and intellectual disability. There is no retinal, renal or liver involvement. No major gene has been associated with this phenotype, but occasional mutations in several genes have been reported $[13,15,67-$ 73].

\section{JS with ocular defect (JS-O)}

The neurological features of JS are present in association to retinal dystrophy (including LCA) with variable age at onset, progression and severity. To date, the most frequently mutated gene in this subgroup is $A H I 1$, which accounts for about $20 \%$ of cases $[39,71,74,75]$.

\section{JS with renal defect (JS-R)}

In this subgroup, neurological signs are associated with renal disease, which is in most cases juvenile $\mathrm{NPH}$, in the absence of retinal involvement. The two genes most commonly mutated in this rare phenotype are NPHP1 and RPGRIP1L [11,76-80].

\section{JS with oculorenal defects (JS-OR)}

This form is characterized by the association of neurological signs of JS with both retinal dystrophy and NPH. About $50 \%$ of patients carry mutations in the CEP290 gene $[10,81-83]$.

\section{JS with hepatic defect (JS-H)}

This subgroup presents the association of JS with CHF. Chorioretinal or optic nerve colobomas and NPH can be part of the phenotype but are not mandatory features. Over $70 \%$ of cases are due to mutations in the TMEM67 gene $[14,47,72,84,85]$.

\section{JS with oro-facio-digital defects (JS-OFD)}

In this subgroup, JS features are associated to bifid or lobulated tongue (often described as soft-tissue nodules or multiple hamartomas), multiple oral frenulae and polydactyly, that is usually mesaxial, with Y-shaped metacarpals $[4,59,86,87]$. Hypothalamic hamartoma or congenital absence of the pituitary gland can be part of this spectrum $[38,86,88]$. This phenotype has been recently associated with mutations in the TMEM216 gene [15]. 
Table 1: Classification of Joubert syndrome and related disorders based on associated clinical features

\begin{tabular}{|c|c|c|c|c|}
\hline Clinical subtypes & $\begin{array}{l}\text { Mandatory } \\
\text { features }\end{array}$ & $\begin{array}{l}\text { Preferentially } \\
\text { associated features* }\end{array}$ & $\begin{array}{l}\text { Previously used } \\
\text { nosology }\end{array}$ & Major gene(s)** \\
\hline \multirow[t]{2}{*}{ Pure Joubert syndrome (JS) } & MTS & & JS & $\begin{array}{l}\text { Mutations in many } \\
\text { genes }\end{array}$ \\
\hline & & & JS type A & \\
\hline \multirow[t]{2}{*}{ JS with ocular defect (JS-O) } & MTS & & & \\
\hline & $\begin{array}{l}\text { Retinal dystrophy } \\
\text { (including LCA) }\end{array}$ & & JS type B & AHI1 \\
\hline \multirow[t]{3}{*}{ JS with renal defect (JS-R) } & MTS & & & NPHP1 \\
\hline & $\mathrm{NPH}$ & & & RPGRIP1L \\
\hline & MTS & & Cerebellooculorenal s. & \\
\hline \multirow[t]{3}{*}{$\begin{array}{l}\text { JS with oculorenal defects } \\
\text { (JS-OR) }\end{array}$} & $\begin{array}{l}\text { Retinal dystrophy } \\
\text { (often LCA) }\end{array}$ & $\begin{array}{l}\text { (CHF reported in few } \\
\text { cases) }\end{array}$ & SLS plus MTS & CEP290 \\
\hline & $\mathrm{NPH}$ & & JS type B & \\
\hline & & & Dekaban-Arima s. & \\
\hline \multirow[t]{2}{*}{ JS with hepatic defect (JS-H) } & MTS & Colobomas & $\mathrm{COACH}$ s. & TMEM67 \\
\hline & $\mathrm{CHF}$ & $\mathrm{NPH}$ & Gentile s. & \\
\hline \multirow{3}{*}{$\begin{array}{l}\text { JS with orofaciodigital } \\
\text { defects (JS-OFD) }\end{array}$} & MTS & & Váradi-Papp s. & \\
\hline & $\begin{array}{l}\text { Lobulated/bifid } \\
\text { tongue (incl. } \\
\text { hamartomas) }\end{array}$ & Cleft lip/palate & Orofaciodigital VI s. & $\begin{array}{l}\text { TMEM216 ( } 2 \\
\text { patients only) }\end{array}$ \\
\hline & Polydactyly & & & \\
\hline
\end{tabular}

\section{Diagnosis}

A diagnosis of JSRD should be suspected in all infants presenting with hypotonia, abnormal eye movements (in particular oculomotor apraxia, but also nystagmus) and developmental delay. The occurrence of abnormalities in the respiratory pattern, i.e. hyperpneas alternating with periods of apnea, reinforces the clinical suspicion of the disease. In these children, a brain MRI is sufficient to confirm or exclude the diagnosis, based on the detection of the MTS (Figure 2).

Once a diagnosis of JSRD has been made, children should enter a diagnostic protocol to assess the possible multiorgan involvement. Ocular investigations include evaluation of visual acuity, ocular motility, fundus oculi and, whenever possible, electroretinogram. Slit lamp examination can disclose abnormalities of the anterior segment of the eye. Kidney and liver function should be tested. Standard urine analysis is also necessary, and special attention should be given to urine specific gravity; should this value be abnormal or towards the lower normal range, a challenge test to assess urinary concentration ability is recommended. This is usually performed with water restriction or, even better, by evaluating urinary specific gravity after stimulation with Desmopressin. Abdominal ultrasound will explore the kidneys (to detect small cysts and loss of corticomedullar differentiation, suggestive of NPH), and the liver (to identify hepatomegaly or structural abnormalities that could underlie CHF). If hepatic involvement is suspected, further liver imaging techniques (such as magnetic reso- 


\begin{tabular}{|c|c|c|}
\hline $\begin{array}{l}\text { PHYSICAL } \\
\text { EXAMINATION }\end{array}$ & $\begin{array}{l}\text { BRAIN MAGNETIC } \\
\text { RESONANCE IMAGING }\end{array}$ & $\begin{array}{l}\text { CNS and DEVELOPMENT } \\
\text { - in neonates and infants prevent respiratory and feeding } \\
\text { problems related to breathing abnormalities and hypotonia } \\
\text { - perform developmental, neuropsychological and behavioral } \\
\text { testing and plan rehabilitation strategy } \\
\text { - electroencephalogram if seizures are suspected }\end{array}$ \\
\hline $\begin{array}{l}\text { - breathing } \\
\text { abnormalities } \\
\text { (++ neonatal) }\end{array}$ & MOLAR TOOTH SIGN & $\begin{array}{l}\text { EYE } \\
\text { - at diagnosis plan ophthalmologic evaluation: visual acuity, } \\
\text { fundoscopy, electroretinogram, slit lamp examination } \\
\text { - in case of positive testing refer to specialist for diagnostic } \\
\text { confirmation, follow-up and rehabilitation }\end{array}$ \\
\hline $\begin{array}{l}\text { - oculomotor apraxia/ } \\
\text { other abnormal eye } \\
\text { movements }\end{array}$ & $\begin{array}{l}\text { other CNS defects: } \\
\text { - polymicrogyria/other } \\
\text { neuronal migration defects }\end{array}$ & $\begin{array}{l}\text { KIDNEY } \\
\text { - in children }(0-16 y) \text { plan kidney evaluation (renal function and } \\
\text { urinary specific gravity, kidney ultrasound, urinary concentration } \\
\text { ability*) at least every two years }\end{array}$ \\
\hline $\begin{array}{l}\text { - ataxia (childhood) } \\
\text { - polydactyly }\end{array}$ & $\begin{array}{l}\text { - pituitary defects/ } \\
\text { hypothalamic hamartoma } \\
\text { " corpus callosum }\end{array}$ & $\begin{array}{l}\text { - in adults check renal function, urinary specific gravity and } \\
\text { kidney ultrasound at diagnosis } \\
\text { - in case of positive testing refer to specialist for diagnostic } \\
\text { confirmation, follow-up and management of nephronophthisis }\end{array}$ \\
\hline - facial dysmorphisms & $\begin{array}{l}\text { - Dandy-Walker } \\
\text { malformation }\end{array}$ & $\begin{array}{l}\text { LIVER } \\
\text { - in children (0-16y) plan hepatic evaluation (liver function and } \\
\text { ultrasound) at least every two years } \\
\text { - in adults check liver function and ultrasound at diagnosis }\end{array}$ \\
\hline - cleft lip/palate & - (meningo) encephalocele & $\begin{array}{l}\text { - in case of positive testing refer to specialist for diagnostic } \\
\text { confirmation, follow-up and management of hepatic fibrosis }\end{array}$ \\
\hline - scoliosis & & $\begin{array}{l}\text { MISCELLANEOUS } \\
\text { - check once for congenital heart defects, situs inversus, } \\
\text { Hirschsprung's disease }\end{array}$ \\
\hline
\end{tabular}

Figure 2 Schematic approach to the diagnosis and management of JSRD. Left: clinical manifestations that - in variable association - may lead to the diagnostic suspicion of JSRD. Middle: the detection of the MTS by brain magnetic resonance imaging confirms the diagnosis; in a subset of patients, other CNS defects may be identified. Right: proposed evaluation protocol for multiorgan involvement. *by water restriction or Desmopressin test.

nance imaging) can support the diagnosis by demonstrating bile ducts proliferation or fibrotic nodules. Diagnosis is then confirmed by liver biopsy.

Possibly associated signs need to be investigated, including pituitary defects, cleft palate, lobulated tongue, congenital heart defects, situs inversus and Hirschsprung disease. A careful assessment of brain imaging is also requested to search for associated CNS malformations (Figure 2).

To date, diagnostic genetic testing is available only for a few genes, while selected laboratories offer molecular testing of known genes on a research basis. Genes to be tested should be prioritized by taking into account the clinical subgroup to which the patient belongs and the available genotype-phenotype correlates (Table 1).

\section{Differential diagnosis}

All conditions displaying neurological (hypotonia, abnormal breathing, abnormal eye movements and developmental delay) and/or organs manifestations seen in JSRD (retinal dystrophy, NPH, CHF, polydactyly) should be considered. In particular, these include other ciliopathies such as isolated nephronophthisis, Senior-Loken syndrome and Bardet Biedl syndrome, as well as cerebellar and brainstem congenital malformations and cerebrooculo-renal syndromes [48,89-91].

\section{Genetic counseling and prenatal diagnosis}

With the exception of rare cases following X-linked recessive inheritance [70], JSRD are transmitted in autosomal recessive fashion, and the recurrence risk for a couple with an affected child is one in four. Prenatal diagnosis is feasible through chorionic villus sampling at around eleven weeks gestation, only in families in which the molecular defect had been previously identified in the proband. To date, published mutation screenings of known genes have allowed the identification of mutations in less than half JSRD patients, making prenatal diagnosis still limited to a subset of families [92]. 
In the remaining families, fetal ultrasound may be useful in at-risk pregnancies, allowing the detection of hypoplasia of the cerebellar vermis and, when present, occipital encephalocele. Polydactyly may also represent a suggestive, although non-specific, feature possibly associated with all JSRD phenotypes [93,94]. Recently, fetal MRI has been acknowledged as the method of choice to delineate posterior fossa malformations, facilitating the diagnosis of the disease before 24 weeks of gestation [9597].

\section{Management and follow-up}

In neonates and infants particular care should be taken in managing respiratory and feeding problems related to either breathing abnormalities or hypotonia. Rehabilitation strategies must be planned for cognitive and behavioral difficulties and specific manifestations such as the visual impairment.

Any abnormal feature identified during the diagnostic assessment should be carefully followed up over time. In particular, the detection of decreased urinary concentration ability often represents the first clue to a diagnosis of $\mathrm{NPH}$ in otherwise asymptomatic patients. This requires a close monitoring to timely recognize and treat early signs of renal failure and to delay the onset of complications such as growth defect or bone disease. If CHF is diagnosed, specific follow-up should be planned to manage possible complications, including portal hypertension and esophageal varices.

\section{Prognosis}

Soon after birth, prognosis is related to the extent and severity of breathing dysregulation. In particular, recurrent episodes of prolonged apneas can be life-threatening and require assisted ventilation. In most cases, these respiratory abnormalities resolve spontaneously in the first months or years of life. Feeding difficulties may represent a problem in a number of patients. Afterwards, prognosis depends mostly on renal and hepatic complications that, if not timely diagnosed and managed, represent the major causes of death in JSRD patients.

\section{List of abbreviations used}

JS: Joubert syndrome; MTS: molar tooth sign; JSRD: Joubert syndrome and related disorders; CNS: central nervous system; LCA: Leber congenital amaurosis; NPH: nephronophthisis; CDK: cystic dysplastic kidneys; CHF: congenital hepatic fibrosis.

\section{Competing interests}

The authors declare that they have no competing interests.

\section{Authors' contributions}

FB and EMV revised the literature and drafted the manuscript; BD critically revised the manuscript for intellectual content. All authors read and approved the final manuscript.

\section{Acknowledgements}

The authors wish to thank Drs. Enrico Bertini and Andrea Rossi for their helpful suggestions and Sheila Pierce for her assistance in writing the manuscript. This work was supported by grant from the Italian Ministry of Health (Ricerca Corrente 2010 to EMV) and by Telethon Foundation (grant \# GGP08145 to EMV).

\section{Author Details}

${ }^{1}$ Mendel Laboratory, Casa Sollievo della Sofferenza Hospital, IRCCS, San Giovanni Rotondo, Italy, 2Department of Biomedical Sciences, Ce.S.I. Aging Research Center, Gabriele d'Annunzio University Foundation, Chieti, Italy, 3Bambino Gesù Children Hospital, IRCCS, Rome, Italy and 4 Department of Medical and Surgical Pediatric Sciences, University of Messina, Messina, Italy

Received: 3 July 2009 Accepted: 8 July 2010

Published: 8 July 2010

\section{References}

1. Joubert M, Eisenring JJ, Andermann F: Familial dysgenesis of the vermis: a syndrome of hyperventilation, abnormal eye movements and retardation. Neurology 1968, 18:302-303.

2. Maria BL, Hoang KB, Tusa RJ, Mancuso AA, Hamed LM, Quisling RG, Hove MT, Fennell EB, Booth-Jones M, Ringdahl DM, Yachnis AT, Creel G, Frerking B: "Joubert syndrome" revisited: key ocular motor signs with magnetic resonance imaging correlation. J Child Neurol 1997, 12:423-430.

3. Satran D, Pierpont ME, Dobyns WB: Cerebello-oculo-renal syndromes including Arima Senior-Loken and $\mathrm{COACH}$ syndromes: more than just variants of Joubert syndrome. Am J Med Genet 1999, 86:459-469.

4. Gleeson JG, Keeler LC, Parisi MA, Marsh SE, Chance PF, Glass IA, Graham JM Jr, Maria BL, Barkovich AJ, Dobyns WB: Molar tooth sign of the midbrainhindbrain junction: occurrence in multiple distinct syndromes. Am J Med Genet A 2004, 125:125-134.

5. Maria BL, Quisling RG, Rosainz LC, Yachnis AT, Gitten J, Dede D, Fennell E: Molar tooth sign in Joubert syndrome: clinical radiologic, and pathologic significance. J Child Neurol 1999, 14:368-376.

6. Yachnis AT, Rorke LB: Neuropathology of Joubert syndrome. J Child Neurol 1999, 14:655-659.

7. Lancaster MA, Gleeson JG: The primary cilium as a cellular signaling center: lessons from disease. Curr Opin Genet Dev 2009, 19:220-229.

8. Badano JL, Mitsuma N, Beales PL, Katsanis N: The Ciliopathies: An Emerging Class of Human Genetic Disorders. Annu Rev Genomics Hum Genet 2006, 7:125-148.

9. Millen KJ, Gleeson JG: Cerebellar development and disease. Curr Opin Neurobiol 2008, 18:12-19.

10. Brancati F, Barrano G, Silhavy JL, Marsh SE, Travaglini L, Bielas SL, Amorini M, Zablocka D, Kayserili H, Al-Gazali L, Bertini E, Boltshauser E, D'Hooghe M, Fazzi E, Fenerci EY, Hennekam RC, Kiss A, Lees MM, Marco E, Phadke SR, Rigoli L, Romano S, Salpietro CD, Sherr EH, Signorini S, Stromme P, Stuart B, Sztriha L, Viskochil DH, Yuksel A, Dallapiccola B, Valente EM, Gleeson JG: CEP290 mutations are frequently identified in the oculo-renal form of Joubert syndrome-related disorders. Am J Hum Genet 2007, 81:104-113.

11. Delous M, Baala L, Salomon R, Laclef C, Vierkotten J, Tory K, Golzio C, Lacoste T, Besse L, Ozilou C, Moutkine I, Hellman NE, Anselme I, Silbermann F, Vesque C, Gerhardt C, Rattenberry E, Wolf MT, Gubler MC, Martinovic J, Encha-Razavi F, Boddaert N, Gonzales M, Macher MA, Nivet $H$, Champion G, Bertheleme JP, Niaudet P, McDonald F, Hildebrandt F, Johnson CA, Vekemans M, Antignac C, Ruther U, Schneider-Maunoury S, ttie-Bitach T, Saunier S: The ciliary gene RPGRIP1L is mutated in cerebello-oculo-renal syndrome (Joubert syndrome type B) and Meckel syndrome. Nat Genet 2007, 39:875-881.

12. Tallila J, Salonen R, Kohlschmidt N, Peltonen L, Kestila M: Mutation spectrum of Meckel syndrome genes: one group of syndromes or several distinct groups? Hum Mutat 2009, 30:E813-E830.

13. Mougou-Zerelli S, Thomas S, Szenker E, Audollent S, Elkhartoufi N, Babarit C, Romano S, Salomon R, Amiel J, Esculpavit C, Gonzales M, Escudier E, Leheup B, Loget P, Odent S, Roume J, Gerard M, Delezoide AL, Khung S, Patrier S, Cordier MP, Bouvier R, Martinovic J, Gubler MC, Boddaert N, Munnich A, Encha-Razavi F, Valente EM, Saad A, Saunier S, Vekemans M, ttie-Bitach T: CC2D2A mutations in Meckel and Joubert syndromes indicate a genotype-phenotype correlation. Hum Mutat 2009, 30:1574-1582 
14. Iannicelli M, Brancati F, Mougou-Zerelli S, Mazzotta A, Thomas S, Elkhartoufi N, Travaglini L, Gomes C, Ardissino GL, Bertini E, Boltshauser E, Castorina P, D'Arrigo S, Fischetto R, Leroy B, Loget P, Bonniere M, Starck L, Tantau J, Gentilin B, Majore S, Swistun D, Flori E, Lalatta F, Pantaleoni C, Penzien J, Grammatico P, Dallapiccola B, Gleeson JG, Attie-Bitach T, Valente EM: Novel TMEM67 mutations and genotype-phenotype correlates in meckelin-related ciliopathies. Hum Mutat 2010, 31:E1319-E1331.

15. Valente EM, Logan CV, Mougou-Zerelli S, Lee JH, Silhavy JL, Brancati F, lannicelli M, Travaglini L, Romani S, Illi B, Adams M, Szymanska K, Mazzotta A, Lee JE, Tolentino JC, Swistun D, Salpietro CD, Fede C, Gabriel S, Russ C, Cibulskis K, Sougnez C, Hildebrandt F, Otto EA, Held S, Diplas BH, Davis EE, Mikula M, Strom CM, Ben-Zeev B, Lev D, Sagie TL, Michelson M, Yaron Y, Krause A, Boltshauser E, Elkhartoufi N, Roume J, Shalev S, Munnich A Saunier S, Inglehearn C, Saad A, Alkindy A, Thomas S, Vekemans M, Dallapiccola B, Katsanis N, Johnson CA, Attie-Bitach T, Gleeson JG: Mutations in TMEM216 perturb ciliogenesis and cause Joubert Meckel and related syndromes. Nat Genet 2010, 42:619-625.

16. Parisi MA, Doherty D, Chance PF, Glass IA: Joubert syndrome (and related disorders) (OMIM 213300). Eur J Hum Genet 2007, 15:511-521.

17. Kroes HY, van Zon PH, van de Putte DF, Nelen MR, Nievelstein RJ, WittebolPost D, van NO, Mancini GM, van der Knaap MS, Kwee ML, Maas SM, Cobben JM, De Nef JE, Lindhout D, Sinke RJ: DNA analysis of AHI1, NPHP1 and CYCLIN D1 in Joubert syndrome patients from the Netherlands. Eur J Med Genet 2008, 51:24-34

18. Saraiva JM, Baraitser M: Joubert syndrome: a review. Am J Med Genet 1992, 43:726-731.

19. Boltshauser $E$, Isler W: Joubert syndrome: episodic hyperpnea abnormal eye movements retardation and ataxia associated with dysplasia of the cerebellar vermis. Neuropadiatrie 1977, 8:57-66.

20. Maria BL, Boltshauser E, Palmer SC, Tran TX: Clinical features and revised diagnostic criteria in Joubert syndrome. J Child Neurol 1999, 14:583-590.

21. Boltshauser E, Herdan M, Dumermuth G, Isler W: Joubert syndrome: clinical and polygraphic observations in a further case. Neuropediatrics 1981, 12:181-191.

22. Braddock BA, Farmer JE, Deidrick KM, Iverson JM, Maria BL: Oromotor and communication findings in joubert syndrome: further evidence of multisystem apraxia. J Child Neurol 2006, 21:160-163.

23. Weiss AH, Doherty D, Parisi M, Shaw D, Glass I, Phillips JO: Eye movement Abnormalities in Joubert Syndrome. Invest Ophthalmol Vis Sci 2009, 50:4669-4677

24. Deonna T, Ziegler AL: Cognitive development and behavior in Joubert syndrome. Biol Psychiatry 1993, 33:854-855.

25. Fennell EB, Gitten JC, Dede DE, Maria BL: Cognition, behavior and development in Joubert syndrome. J Child Neuro/ 1999, 14:592-596.

26. Gitten J, Dede D, Fennell E, Quisling R, Maria BL: Neurobehavioral development in Joubert syndrome. J Child Neurol 1998, 13:391-397.

27. Steinlin M, Schmid M, Landau K, Boltshauser E: Follow-up in children with Joubert syndrome. Neuropediatrics 1997, 28:204-211.

28. Valente EM, Marsh SE, Castori M, xon-Salazar T, Bertini E, Al-Gazali L, Messer J, Barbot C, Woods CG, Boltshauser E, Al-Tawari AA, Salpietro CD, Kayserili H, Sztriha L, Gribaa M, Koenig M, Dallapiccola B, Gleeson JG: Distinguishing the four genetic causes of Jouberts syndrome-related disorders. Ann Neurol 2005, 57:513-519.

29. Poretti A, Dietrich AF, Brancati F, Dallapiccola B, Valente EM, Boltshauser E: Normal cognitive functions in joubert syndrome. Neuropediatrics 2009, 40:287-290

30. Maria BL, Bozorgmanesh A, Kimmel KN, Theriaque D, Quisling RG: Quantitative assessment of brainstem development in Joubert syndrome and Dandy-Walker syndrome. J Child Neurol 2001, 16:751-758

31. Genel F, Atlihan F, Ozdemir D, Targan S: Development of hydrocephalus in a patient with Joubert syndrome. J Postgrad Med 2004, 50:153.

32. Haug K, Khan S, Fuchs S, Konig R: OFD II, OFD VI, and Joubert syndrome manifestations in 2 sibs. Am J Med Genet 2000, 91:135-137.

33. Kendall B, Kingsley D, Lambert SR, Taylor D, Finn P: Joubert syndrome: a clinico-radiological study. Neuroradiology 1990, 31:502-506.

34. Shian WJ, Chi CS, Mak SC, Chen CH: Joubert syndrome in Chinese infants and children: a report of four cases. Zhonghua Yi Xue Za Zhi (Taipei) 1993, 52:342-345
35. ten Donkelaar HJ, Hoevenaars F, Wesseling P: A case of Joubert's syndrome with extensive cerebral malformations. Clin Neuropathol 2000, 19:85-93

36. van Dorp DB, Palan A, Kwee ML, Barth PG, van der Harten JJ: Joubert syndrome: a clinical and pathological description of an affected male and a female fetus from the same sibship. Am J Med Genet 1991, 40:100-104

37. Zamponi N, Rossi B, Messori A, Polonara G, Regnicolo L, Cardinali C: Joubert syndrome with associated corpus callosum agenesis. Eur J Paediatr Neurol 2002, 6:63-66.

38. Al-Gazali LI, Sztriha L, Punnose J, Shather W, Nork M: Absent pituitary gland and hypoplasia of the cerebellar vermis associated with partial ophthalmoplegia and postaxial polydactyly: a variant of orofaciodigital syndrome VI or a new syndrome? J Med Genet 1999, 36:161-166

39. Dixon-Salazar T, Silhavy JL, Marsh SE, Louie CM, Scott LC, Gururaj A, AlGazali L, Al-Tawari AA, Kayserili H, Sztriha L, Gleeson JG: Mutations in the AHI1 gene encoding jouberin cause Joubert syndrome with cortical polymicrogyria. Am J Hum Genet 2004, 75:979-987.

40. Giordano L, Vignoli A, Pinelli L, Brancati F, Accorsi P, Faravelli F, Gasparott R, Granata T, Giaccone G, Inverardi F, Frassoni C, Dallapiccola B, Valente EM, Spreafico R: Joubert syndrome with bilateral polymicrogyria: clinical and neuropathological findings in two brothers. Am J Med Genet A 2009, 149A:1511-1515.

41. Wang $P$, Chang FM, Chang $\mathrm{CH}$, Yu CH, Jung YC, Huang CC: Prenatal diagnosis of Joubert syndrome complicated with encephalocele using two-dimensional and three-dimensional ultrasound. Ultrasound Obstet Gynecol 1999, 14:360-362

42. Lambert SR, Kriss A, Gresty M, Benton S, Taylor D: Joubert syndrome. Arch Ophthalmol 1989, 107:709-713.

43. Tusa RJ, Hove MT: Ocular and oculomotor signs in Joubert syndrome. J Child Neurol 1999, 14:621-627.

44. Khan AO, Oystreck DT, Seidahmed MZ, AIDrees A, Elmalik SA, Alorainy IA Salih MA: Ophthalmic features of Joubert syndrome. Ophthalmology 2008, 115:2286-2289.

45. Sturm V, Leiba H, Menke MN, Valente EM, Poretti A, Landau K, Boltshauser E: Ophthalmological findings in Joubert syndrome. Eye 2010 24:222-225

46. Gregory-Evans CY, Williams MJ, Halford S, Gregory-Evans K: Ocular coloboma: a reassessment in the age of molecular neuroscience. JMed Genet 2004, 41:881-891.

47. Brancati F, lannicelli M, Travaglini L, Mazzotta A, Bertini E, Boltshauser E, D'Arrigo S, Emma F, Fazzi E, Gallizzi R, Gentile M, Loncarevic D, MejaskiBosnjak V, Pantaleoni C, Rigoli L, Salpietro CD, Signorini S, Stringini GR, Verloes A, Zablocka D, The International JSRD Study Group, Dallapiccola B, Gleeson JG, Valente EM: MKS3/TMEM67 mutations are a major cause of COACH Syndrome a Joubert Syndrome related disorder with liver involvement. Hum Mutat 2009, 30:E432-E442.

48. Salomon R, Saunier S, Niaudet P: Nephronophthisis. Pediatr Nephrol 2009, 24:2333-2344

49. Dekaban AS: Hereditary syndrome of congenital retinal blindness (Leber), polycystic kidneys and maldevelopment of the brain. Am J Ophthalmol 1969, 68:1029-1037.

50. Matsuzaka T, Sakuragawa N, Nakayama H, Sugai K, Kohno Y, Arima M: Cerebro-oculo-hepato-renal syndrome (Arima' syndrome): a distinct clinicopathological entity. J Child Neurol 1986, 1:338-346.

51. Kumada S, Hayashi M, Arima K, Nakayama H, Sugai K, Sasaki M, Kurata K, Nagata M: Renal disease in Arima syndrome is nephronophthisis as in other Joubert-related Cerebello-oculo-renal syndromes. Am J Med Genet A 2004, 131:71-76.

52. Salonen R: The Meckel syndrome: clinicopathological findings in 67 patients. Am J Med Genet 1984, 18:671-689.

53. Chen CP: Meckel syndrome:genetics perinatal findings and differential diagnosis. Taiwan J Obstet Gynecol 2007, 46:9-14.

54. Desmet VJ: Congenital diseases of intrahepatic bile ducts: variations on the theme "ductal plate malformation". Hepatology 1992, 16:1069-1083.

55. Lewis SM, Roberts EA, Marcon MA, Harvey E, Phillips MJ, Chuang SA, Buncic JR, Clarke JT: Joubert syndrome with congenital hepatic fibrosis: an entity in the spectrum of oculo-encephalo-hepato-renal disorders. Am J Med Genet 1994, 52:419-426. 
56. Verloes A, Lambotte C: Further delineation of a syndrome of cerebellar vermis hypo/aplasia, oligophrenia congenital ataxia coloboma, and hepatic fibrosis. Am J Med Genet 1989, 32:227-232.

57. Pellegrino JE, Lensch MW, Muenke M, Chance PF: Clinical and molecular analysis in Joubert syndrome. Am J Med Genet 1997, 72:59-62.

58. Chance PF, Cavalier L, Satran D, Pellegrino JE, Koenig M, Dobyns WB: Clinical nosologic and genetic aspects of Joubert and related syndromes. J Child Neurol 1999, 14:660-666.

59. Varadi V, Szabo L, Papp Z: Syndrome of polydactyly cleft lip/palate or lingual lump and psychomotor retardation in endogamic gypsies. J Med Genet 1980, 17:119-122

60. Hodgkins PR, Harris CM, Shawkat FS, Thompson DA, Chong K, Timms C, Russell-Eggitt I, Taylor DS, Kriss A: Joubert syndrome: long-term followup. Dev Med Child Neurol 2004, 46:694-699.

61. Braddock SR, Henley KM, Maria BL: The face of Joubert syndrome: a study of dysmorphology and anthropometry. Am J Med Genet A 2007, 143:3235-3242.

62. Elmali M, Ozmen Z, Ceyhun M, Tokatlioglu O, Incesu L, Diren B: Joubert syndrome with atrial septal defect and persistent left superior vena cava. Diagn Interv Radiol 2007, 13:94-96.

63. Aydinoz S, Ersen A, Karademir F, Suleymanoglu S, Ozkaya H, Gocmen I: A case of cerebello-oculo-renal syndrome with situs inversus totalis: a new phenotype. J Child Neurol 2007, 22:204-207.

64. Ozyurek H, Kayacik OE, Gungor O, Karagoz F: Rare association of Hirschsprung's disease and Joubert syndrome. Eur J Pediatr 2008, 167:475-477.

65. Lorda-Sanchez I, Ayuso C, Ibanez A: Situs inversus and hirschsprung disease: two uncommon manifestations in Bardet-Biedl syndrome. Am J Med Genet 2000, 90:80-81.

66. de Pontual L, Zaghloul NA, Thomas S, Davis EE, McGaughey DM, Dollfus H, Baumann C, Bessling SL, Babarit C, Pelet A, Gascue C, Beales P, Munnich A, Lyonnet S, Etchevers H, Attie-Bitach T, Badano JL, McCallion AS, Katsanis $\mathrm{N}$, Amiel J: Epistasis between RET and BBS mutations modulates enteric innervation and causes syndromic Hirschsprung disease. Proc Natl Acad Sci USA 2009, 106:13921-13926.

67. Edvardson S, Shaag A, Zenvirt S, Erlich Y, Hannon GJ, Shanske AL, Gomori JM, Ekstein J, Elpeleg O: Joubert syndrome 2 (JBTS2) in Ashkenazi Jews is associated with a TMEM216 mutation. Am J Hum Genet 2010, 86:93-97.

68. Bielas SL, Silhavy JL, Brancati F, Kisseleva MV, Al-Gazali L, Sztriha L, Bayoumi RA, Zaki MS, bdel-Aleem A, Rosti RO, Kayserili H, Swistun D, Scott LC, Bertini E, Boltshauser E, Fazzi E, Travaglini L, Field SJ, Gayral S, Jacoby M, Schurmans S, Dallapiccola B, Majerus PW, Valente EM, Gleeson JG: Mutations in INPP5E, encoding inositol polyphosphate-5-phosphatase E link phosphatidyl inositol signaling to the ciliopathies. Nat Genet 2009, 41:1032-1036.

69. Cantagrel V, Silhavy JL, Bielas SL, Swistun D, Marsh SE, Bertrand JY, Audollent S, Attie-Bitach T, Holden KR, Dobyns WB, Traver D, Al-Gazali L, Ali BR, Lindner TH, Caspary T, Otto EA, Hildebrandt F, Glass IA, Logan CV, Johnson CA, Bennett C, Brancati F, Valente EM, Woods CG, Gleeson JG: Mutations in the cilia gene ARL13B lead to the classical form of Joubert syndrome. Am J Hum Genet 2008, 83:170-179.

70. Coene KL, Roepman R, Doherty D, Afroze B, Kroes HY, Letteboer SJ, Ngu $L H$, Budny $B$, van WE, Gorden NT, Azhimi M, Thauvin-Robinet C, Veltman $J A$, Boink M, Kleefstra T, Cremers FP, van BH, de Brouwer AP: OFD1 is mutated in X-linked Joubert syndrome and interacts with LCA5encoded lebercilin. Am J Hum Genet 2009, 85:465-481.

71. Valente EM, Brancati F, Silhavy JL, Castori M, Marsh SE, Barrano G, Bertini E, Boltshauser E, Zaki MS, bdel-Aleem A, bdel-Salam GM, Bellacchio E, Battini R, Cruse RP, Dobyns WB, Krishnamoorthy KS, Lagier-Tourenne C, Magee A, Pascual-Castroviejo I, Salpietro CD, Sarco D, Dallapiccola B, Gleeson JG: AHI1 gene mutations cause specific forms of Joubert syndromerelated disorders. Ann Neurol 2006, 59:527-534.

72. Baala L, Romano S, Khaddour R, Saunier S, Smith UM, Audollent S, Ozilou C, Faivre L, Laurent N, Foliguet B, Munnich A, Lyonnet S, Salomon R, EnchaRazavi F, Gubler MC, Boddaert N, de LP, Johnson CA, Vekemans M, Antignac C, Attie-Bitach T: The Meckel-Gruber syndrome gene MKS3, is mutated in Joubert syndrome. Am J Hum Genet 2007, 80:186-194.

73. Gorden NT, Arts HH, Parisi MA, Coene KL, Letteboer SJ, van Beersum SE, Mans DA, Hikida A, Eckert M, Knutzen D, Alswaid AF, Ozyurek H, Dibooglu S, Otto EA, Liu Y, Davis EE, Hutter CM, Bammler TK, Farin FM, Dorschner M, Topcu M, Zackai EH, Rosenthal P, Owens KN, Katsanis N, Vincent JB,
Hildebrandt F, Rubel EW, Raible DW, Knoers NV, Chance PF, Roepman R, Moens CB, Glass IA, Doherty D: CC2D2A Is Mutated in Joubert Syndrome and Interacts with the Ciliopathy-Associated Basal Body Protein CEP290. Am J Hum Genet 2008, 83:559-571.

74. Ferland RJ, Eyaid W, Collura RV, Tully LD, Hill RS, Al-Nouri D, Al-Rumayyan A, Topcu M, Gascon G, Bodell A, Shugart YY, Ruvolo M, Walsh CA: Abnormal cerebellar development and axonal decussation due to mutations in AHI1 in Joubert syndrome. Nat Genet 2004, 36:1008-1013.

75. Parisi MA, Doherty D, Eckert ML, Shaw DW, Ozyurek H, Aysun S, Giray O, Al SA, AI SS, Dohayan N, Bakhsh E, Indridason OS, Dobyns WB, Bennett CL, Chance PF, Glass IA: AHI1 mutations cause both retinal dystrophy and renal cystic disease in Joubert syndrome. J Med Genet 2006, 43:334-339.

76. Parisi MA, Bennett CL, Eckert ML, Dobyns WB, Gleeson JG, Shaw DW, McDonald R, Eddy A, Chance PF, Glass IA: The NPHP1 gene deletion associated with juvenile nephronophthisis is present in a subset of individuals with Joubert syndrome. Am J Hum Genet 2004, 75:82-91.

77. Castori M, Valente EM, Donati MA, Salvi S, Fazzi E, Procopio E, Galluccio T, Emma F, Dallapiccola B, Bertini E: NPHP1 gene deletion is a rare cause of Joubert syndrome related disorders. JMed Genet 2005, 42:e9.

78. Arts HH, Doherty D, van Beersum SE, Parisi MA, Letteboer SJ, Gorden NT, Peters TA, Marker T, Voesenek K, Kartono A, Ozyurek H, Farin FM, Kroes HY, Wolfrum U, Brunner HG, Cremers FP, Glass IA, Knoers NV, Roepman R: Mutations in the gene encoding the basal body protein RPGRIP1L, a nephrocystin-4 interactor cause Joubert syndrome. Nat Genet 2007, 39:882-888.

79. Brancati F, Travaglini L, Zablocka D, Boltshauser E, Accorsi P, Montagna G, Silhavy JL, Barrano G, Bertini E, Emma F, Rigoli L, Dallapiccola B, Gleeson $J G$, Valente EM: RPGRIP1L mutations are mainly associated with the cerebello-renal phenotype of Joubert syndrome-related disorders. Clin Genet 2008, 74:164-170.

80. Wolf MT, Saunier S, O'Toole JF, Wanner N, Groshong T, Attanasio M, Salomon R, Stallmach T, Sayer JA, Waldherr R, Griebel M, Oh J, Neuhaus TJ, Josefiak U, Antignac C, Otto EA, Hildebrandt F: Mutational analysis of the RPGRIP1L gene in patients with Joubert syndrome and nephronophthisis. Kidney Int 2007, 72:1520-1526.

81. Valente EM, Silhavy JL, Brancati F, Barrano G, Krishnaswami SR, Castori M, Lancaster MA, Boltshauser E, Boccone L, Al-Gazali L, Fazzi E, Signorini S, Louie CM, Bellacchio E, Bertini E, Dallapiccola B, Gleeson JG: Mutations in CEP290, which encodes a centrosomal protein cause pleiotropic forms of Joubert syndrome. Nat Genet 2006, 38:623-625.

82. Sayer JA, Otto EA, O'Toole JF, Nurnberg G, Kennedy MA, Becker C, Hennies HC, Helou J, Attanasio M, Fausett BV, Utsch B, Khanna H, Liu Y, Drummond I, Kawakami I, Kusakabe T, Tsuda M, Ma L, Lee H, Larson RG, Allen SJ, Wilkinson CJ, Nigg EA, Shou C, Lillo C, Williams DS, Hoppe B, Kemper MJ, Neuhaus T, Parisi MA, Glass IA, Petry M, Kispert A, Gloy J, Ganner A, Walz G, Zhu X, Goldman D, Nurnberg P, Swaroop A, Leroux MR, Hildebrandt F: The centrosomal protein nephrocystin- 6 is mutated in Joubert syndrome and activates transcription factor ATF4. Nat Genet 2006, 38:674-681.

83. Helou J, Otto EA, Attanasio M, Allen SJ, Parisi M, Glass I, Utsch B, Hashmi S, Fazzi E, Omran H, O' TJ, Sayer J, Hildebrandt F: Mutation analysis of NPHP6/CEP290 in patients with Joubert-Syndrome and Senior-LokenSyndrome. J Med Genet 2007, 44:657-663.

84. Otto EA, Tory K, Attanasio M, Zhou W, Chaki M, Paruchuri Y, Wise EL, Utsch B, Wolf MT, Becker C, Nurnberg G, Nurnberg P, Nayir A, Saunier S, Antignac C, Hildebrandt F: Hypomorphic Mutations in Meckelin (MKS3/TMEM67) cause Nephronophthisis with Liver Fibrosis (NPHP11). J Med Genet 2009, 46:663-670.

85. Doherty D, Parisi MA, Finn LS, Gunay-Aygun M, Al-Mateen M, Bates D, Clericuzio C, Demir H, Dorschner M, van Essen AJ, Gahl WA, Gentile M, Gorden NT, Hikida A, Knutzen D, Ozyurek H, Phelps I, Rosenthal P, Verloes A, Weigand $H$, Chance PF, Dobyns WB, Glass IA: Mutations in 3 genes (MKS3, CC2D2A and RPGRIP1L) cause COACH syndrome (Joubert syndrome with congenital hepatic fibrosis). J Med Genet 2010, 47:8-21.

86. Munke M, McDonald DM, Cronister A, Stewart JM, Gorlin RJ, Zackai EH: Oral-facial-digital syndrome type VI (Varadi syndrome): further clinical delineation. Am J Med Genet 1990, 35:360-369.

87. Chodirker BN, Shah NS, Bunge MK, Reed MH: Another case of VaradiPapp Syndrome with a molar tooth sign. Am J Med Genet A 2005, 136A:416-417.

88. Stephan MJ, Brooks KL, Moore DC, Coll EJ, Goho C: Hypothalamic hamartoma in oral-facial-digital syndrome type VI (Varadi syndrome). Am J Med Genet 1994, 51:131-136. 
89. Schurman SJ, Scheinman SJ: Inherited cerebrorenal syndromes. Nat Rev Nephrol 2009, 5:529-538.

90. Adams NA, Awadein A, Toma HS: The retinal ciliopathies. Ophthalmic Genet 2007, 28:113-125.

91. Barkovich AJ, Millen KJ, Dobyns WB: A developmental and genetic classification for midbrain-hindbrain malformations. Brain 2009, 132:3199-3230.

92. Valente EM, Brancati F, Dallapiccola B: Genotypes and phenotypes of Joubert syndrome and related disorders. Eur J Med Genet 2008, 51:1-23.

93. Aslan H, Ulker V, Gulcan EM, Numanoglu C, Gul A, Agar M, Ark HC:

Prenatal diagnosis of Joubert syndrome: a case report. Prenat Diagn 2002, 22:13-16.

94. Aslan H, Yildirim G, Ongut C, Ceylan Y: Termination of pregnancy for fetal anomaly. Int J Gynaecol Obstet 2007, 99:221-224.

95. Doherty D, Glass IA, Siebert JR, Strouse PJ, Parisi MA, Shaw DW, Chance PF, Barr M Jr, Nyberg D: Prenatal diagnosis in pregnancies at risk for Joubert syndrome by ultrasound and MRI. Prenat Diagn 2005, 25:442-447.

96. Fluss J, Blaser S, Chitayat D, Akoury H, Glanc P, Skidmore M, Raybaud C Molar tooth sign in fetal brain magnetic resonance imaging leading to the prenatal diagnosis of Joubert syndrome and related disorders. J Child Neurol 2006, 21:320-324.

97. Saleem SN, Zaki MS: Role of MR imaging in prenatal diagnosis of pregnancies at risk for Joubert syndrome and related cerebellar disorders. AJNR Am J Neuroradiol 2010, 31:424-429.

doi: $10.1186 / 1750-1172-5-20$

Cite this article as: Brancati et al., Joubert Syndrome and related disorders Orphanet Journal of Rare Diseases 2010, 5:20

Submit your next manuscript to BioMed Central and take full advantage of:

- Convenient online submission

- Thorough peer review

- No space constraints or color figure charges

- Immediate publication on acceptance

- Inclusion in PubMed, CAS, Scopus and Google Scholar

- Research which is freely available for redistribution

Submit your manuscript at www.biomedcentral.com/submit
Ciomed Central 